\title{
Pengaruh Metode Reciprocal Teaching terhadap Kemampuan Berpikir Kreatif Siswa SMA Kelas X di SMA Kae Woha Tahun Pelajaran 2017/2018
}

\author{
Nurhayati Sarib ${ }^{1}$, Mariamah $^{2}$, Muslim $^{3}$, Fatmah $^{4}$ \\ STKIP Taman Siswa Bima \\ ${ }^{2}$ mariamahmariamah85@yahoo.co.id
}

\begin{abstract}
ABSTRAK
Penelitian ini bertujuan untuk mengetahui pengaruh Reciprocal Teaching terhadap kemampuan berpikir kreatif siswa kelas X di SMA KAE Woha tahun pelajaran 2017/2018. Jenis penelitian ini adalah quasi eksperimen (Eksperimen Semu). Adapun sampel dalam penelitian ini adalah siswa kelas X SMA KAE Woha yang terdiri dari dua kelas yaitu kelas X MIA/IPA-I sebagai kelas eksperimen dan kelas $\mathrm{X}$ MIA/IPA-2 sebagai kelas kontrol. Instrumen penelitian yang digunakan untuk mengukur kemampuan berpikir kreatif adalah soal esay. Kriteria pengujiannya adalah $\mathrm{H}_{0}$ ditolak jika $t_{\text {hitung }} \geq \mathrm{t}_{\text {tabel }}$ atau nilai signifikansi lebih kecil 0,05 pada taraf sinikansi $\alpha=5 \%$. Hasil Uji hipotesis menggunakan bantuan program SPSS 16 for window menunjukkan nilai $\mathrm{t}=4,128$ atau nilai signifikansi sebesar 0,000. Jika dikaitkan dengan nilai signifikansi 0,05 dan nilai t hitung maka $\mathrm{H}_{a}$ diterima. Sehingga dapat disimpulkan bahwa terdapat pengaruh penggunaan metode reciprocal teaching terhadap kemampuan berpikir kreatif siswa.
\end{abstract}

Kata Kunci: Reciprocal Teaching, Berpikir Kreatif Siswa

\section{PENDAHULUAN}

Tujuan mata pelajaran matematika adalah siswa mampu bernalar/berpikir, melakukan manipulasi Matematika dalam membuat generalisasi, menyusun bukti atau menjelaskan gagasan dan peryataan matematika (Fatmah \& Rahman. A: 2017) Tujuan-tujuan tersebut belum seutuhnya dicapai dalam pembelajaran matematika. Ketidak tercapainya tujuan pembelajaran matematika tersebut diakibatkan berbagai kendala seperti kenyataan dilapangan bahwa Proses pembelajaran matematika di SMA KAE lebih cenderung kurang kreatif, dan kurang variatif sehingga membuat peserta didik pasif dalam proses pembelajaran, akibatnya untuk menumbuhkan kemampuan berpikir kreatif siswa pun sangatlah sulit. Hal tersebut terlihat dari kurangnya siswa untuk membuat dan mengajukan pertanyaan, masih banyak siswa yang belum mampu menyelesaikan masalah yang diberikan, serta siswa dalam menyelesaikan masalah kurang sistimatis dalam menguraikan jawaban (sumber: ibu Sri Susanti, S.Pd). Adapun data ril dari hasil ulangan semester ganjil tahun pelajaran 2015/2016, Data kemampuan berpikir kreatif siswa semester ganjil kelas X IPA di SMA Kae Woha Tahun Pelajaran 2015/2016 sebesar
$65 \%$ dan nilai rata-rata 65 dari $\mathrm{kkm} 75$ pada materi persamaan dan pertidaksamaan linier 1 variabel

Pada saat siswa diberikan materi oleh gurunya, siswa tidak menghiraukan, mereka hanya bermain-main saja atau tidak peduli dan disaat guru menanyakan kembali materi tersebut mereka tidak bisa menjawab pertanyaan dari gurunya. Hal tersebut terlihat dari kurangnya siswa untuk mengajukan pertanyaan, masih banyak siswa yang belum mampu menyelesaikan masalah.

Untuk mengatasi masalah di atas diperlukan perbaikan proses pembelajaaran matematika guna meningkatkan kreativitas berpikir siswa dalam pembelajaran matematika. Maka dari itu penelitian ini mencoba dengan model pembelajaran yang kreatif yakni model Reciprocal Teaching.

Model pembelajaran Reciprocal teaching merupakan salah satu model pembelajaran yang memiliki empat strategi yaitu merangkum, menyusun pertanyaan dan menyelesaikannya, menjelaskan kembali pengetahuan yang telah diperoleh kemudian memprediksi pertanyaan apa selanjutnya dari persoalan yang disodorkan kepada siswa. Dari strategi tersebut dapat dilihat 
bahwa model pembelajaran ini banyak menuntut kemampuan berpikir siswa terutama berpikir dalam tingkatan yang lebih tinggi yaitu berpikir kreatif. Dengan berpikir kreatif memungkinkan siswa untuk mempelajari masalah secara sistematis, menghadapi berjuta tantangan dengan cara yang terorganisasi, merumuskan pertanyaan inovatif, dan merancang solusi orisinal dan Reciprocal Teaching merupakan sebuah model pembelajaran yang memenuhi indikator yang ada pada kemampuan berpikir kreatif siswa.

Reciprocal teaching merupakan strategi pembelajaran berdasarkan prinsip-prinsip pengajuan pertanyaan dimana ketrampilanketrampilan metakognitif siswa diajarkan melalui pengajaran langsung dan pemodelan oleh guru.

Model reciprocal teaching (pembelajaran terbalik) merupakan salah satu model pembelajaran kooperatif yang menekankan pada partisipasi dan aktivitas siswa dalam proses pembelajaran. Dengan pembelajaran terbalik ini siswa diajarkan empat strategi yaitu: (1) membuat rangkuman, (2) menyusun pertanyaan, (3) memprediksi jawaban, (4) dan menjelaskan kembali isi materi (bacaan) tersebut kepada siswa lain. Reciprocal Teaching (pembelajaran terbalik) dalam pembelajaran Matematika dapat membelajarkan siswa untuk belajar mandiri dengan menerapkan empat strategi pemahaman tersebut melalui bacaan yang diberikan oleh guru (Antari, Sujana, Wiarta: 2013)

Reciprocal teaching merupakan salah satu model pembelajaran yang dilaksanakan agar tujuan pembelajaran tercapai melalui proses belajar mandiri, model reciprocal teaching memiliki 4 tahapan pembelajaran, yaitu 1) summarizing, 2) question generating, 3) clarifying, dan 4) predicting. Pada tahap summarizing, kegiatan yang dilaksanakan bertujuan untuk membantu siswa mengakses pengetahuan awal yang telah mereka miliki, mendorong siswa untuk berpikir, dan memotivasi siswa untuk belajar. Pada tahap ini siswa diajak mencari ide pokok dalam bacaan dan menemukan kata kunci yang penting dalam bacaan, kemudian mencatatnya dalam buku catatan. Menurut Misi
Mayona (2012) mencatat materi pelajaran bertujuan meningkatkan daya ingat, sehingga konsep dapat dipahami dengan baik.

\section{Sintaks Model Reciprocal Teaching}

Terdapat 4 tahap dalam menggunakan model reciprocal teaching yang diuaraikan sebagai berikut:

Tahap yang pertama adalah tahap summarizing, tahap ini bertujuan untuk menentukan intisari dari materi pembelajaran. Tahap ini memberikan kesempatan kepada siswa untuk mengidentifikasi informasi penting dalam bacaan. Melalui kegiatan pada tahap summarizing diharapkan minat dan rasa ingin tahu siswa tentang topik yang akan dipelajari muncul.

Tahap kedua adalah question generating, dimana siswa dikondisikan untuk berdiskusi dalam kelompok mengerjakan tugas yang diberikan. Siswa membuat pertanyaan berhubungan dengan konsep yang kurang dipahaminya dan diajukan kepada kelompok yang tampil menjelaskan materi pada tahap clarifying. Tahap question generating digunakan untuk memonitor sejauh mana pemahaman siswa terhadap konsep yang sedang dipelajari Selanjutnya,

Tahap ketiga adalah clarifying, bertujuan untuk melengkapi, mengklarifikasi, dan memodifikasi konsep yang baru saja dikonstruk siswa pada tahap sebelumnya. Pada tahap ini, siswa mempresentasikan pengetahuan mereka di depan kelas dan siswa lain diberi kesempatan untuk memberi tanggapan. Pada tahap penjelasan siswa menemukan istilah-istilah dari konsep yang dipelajari. Peran guru pada tahap ini antara lain mendorong siswa untuk menjelaskan konsep dengan kalimat mereka sendiri. Sejalan dengan pendapat yang kemukakan pemahaman konsep dapat terbentuk jika seseorang mampu menyampaikan kembali pengetahuan yang telah diperolehnya baik secara lisan maupun tulisan. Tahap clarifying digunakan untuk mengevaluasi sejauh mana pemahaman siswa terhadap materi pembelajaran. Pada dasarnya tujuan tahap clarifying adalah mengecek pemahaman konsep yang dimiliki siswa apakah sudah benar, masih salah atau mungkin sebagian benar atau sebagian salah. Apabila terjadi 
kekeliruan dalam memahami konsep matematika, guru yang meluruskannya.

Tahap ke empat adalah predicting, Pada tahap ini siswa diharapkan memperluas pemahaman mereka mengenai konsep atau pengetahuan yang baru saja mereka konstruk. Siswa diminta menerapkan konsep atau pengetahuan mereka dalam berbagai pertanyaan yang diberikan oleh siswa dari kelompok lain. Salah satu cara yang dapat ditempuh guru untuk mengoptimalkan model reciprocal teaching khususnya pada kelas besar dengan mengelompokkan siswa dalam kelompok-kelompok kecil. Suasana belajar dalam kelompok dapat membantu siswa untuk saling memberikan umpan balik diantara anggota kelompok. Selain itu, belajar berkelompok merupakan aspek penting dalam proses mengkonstruksi pengetahuan karena dapat membuka peluang untuk terjadinya tukar pendapat, mempertahankan argumentasi, negosiasi antar siswa atau kelompok, sehingga memancing siswa berpartisipasi aktif dalam pembelajaran.

Adapun kelebihan dari model Reciprocal Teaching adalah Pertama, melatih kemampuan peserta didik belajar mandiri, sehingga peserta didik dalam belajar mandiri dapat ditingkatkan. Kedua, melatih peserta didik untuk menjelaskan kembali materi yang dipelajari kepada pihak lain. Dengan demikian penerapan pembelajaran ini dapat dipakai untuk melatih peserta didik tampil di depan umum. Ketiga, orientasi pembelajaran adalah investigasi dan penemuan yang pada dasarnya adalah pemecahan masalah. Dengan demikian kemampuan bernalar peserta didik juga semakin berkembang. Keempat, mempertinggi kemampuan peserta didik dalam memecahkan masalah.

Sedangkan kelemahan adalah Reciprocal teaching menuntut peserta didik untuk selalu aktif dalam kegiatan pembelajaran, sehingga hal ini menjadikan sebagian dari peserta didik tidak percaya diri untuk dapat tampil atau menunjukkan kemampuannya di depan temanteman mereka, dan bisa jadi peserta didik yang aktif hanyalah orang-orang itu saja. Dengan demikian, peserta didik yang belum bisa percaya diri merasa kesulitan dalam menerima pelajaran.
Semua orang diasumsikan kreatif, tetapi derajat kreativitasnya berbeda. Keadaan ini menunjukkan adanya tingkat kemampuan berpikir kreatif seseorang yang berbeda. Ide tentang tingkat kemampuan berpikir kreatif telah diungkapkan oleh beberapa ahli, antara lain oleh De Bono, Gotoh, dan Krulik \& Rudnick (Siswono: 2007). Tingkat tersebut bersifat umum dan tidak dengan tegas memperlihatkan karakteristik berpikir kreatif dalam matematika. Berpikir kreatif dalam matematika merupakan kombinasi berpikir logis dan berpikir divergen yang memperhatikan fleksibilitas, kefasihan dan kebaruan dalam memecahkan maupun mengajukan masalah. Penjenjangan kemampuan berpikir kreatif siswa dalam matematika menurut Siswono adalah sebagai berikut Sangat Kreatif, Kreatif Cukup Kreatif, Kurang Kreatif, dan Tidak Kreatif.

Menurut DePoter (Pasiak: 1999), ada empat langkah penting dalam berfikir kreatif, yakni: 1) dalam berfikir jangan cepat puas dan jangan menerima apa adanya, 2) jangan terpaku pada satu cara, 3) pertajam rasa ingin tahu, 4) perlu pelatihan otak. Ini berarti bahwa berfikir kreatif bukanlah sebuah proses yang terorganisasi, melainkan sebuah kebiasaan dari fikiran yang dilatih dengan memperhatikan intuisi, menghidupkan imajinasi, mengungkapkan kemungkinan-kemungkinan baru, membuka sudut pandang yang menakjubkan dan membangkitkan ide-ide yang tidak terduga. Johnson menyatakan bahwa berfikir kreatif adalah aktifitas mental yang membutuhkan ketekunan, disiplin diri, dan perhatian penuh. Aktifitas mental yang dimaksud adalah; 1) mengajukan pertanyaan, 2) mempertimbangkan informasi baru dan ide yang tidak lazim dengan fikiran terbuka, 3) membangun keterkaitan, khususnya diantara hal-hal yang berbeda, 4) menghubungkan berbagai hal dengan bebas, 5) menerapkan imajinasi pada setiap situasi untuk menghasilkan hal baru yang berbeda, 6) mendengarkan intuisi

Selanjutnya pengertian berpikir kreatif adalah sebuah kebiasaan dari pikiran yang dilatih dengan memperhatikan intuisi, menghidupkan imajinasi, mengungkapkan kemungkinan- 
kemungkinan baru, membuka sudut pandang yang menakjubkan dan membangkitkan ide-ide yang tidak terduga. Berpikir kreatif membutuhkan ketekunan, disiplin diri dan perhatian penuh yang meliputi aktivitas mental 1) mengajukan pertanyaan, mempertimbangkan informasi baru dan ide yang tidak lazim dengan pikiran terbuka, 3) membangun keterkaitan khususnya di antara hal-hal yang berbeda, 4) menghubunghubungkan berbagai hal yang bebas, 5) menerapkan imajinasi pada setiap situasi untuk menghasilkan hal yang baru dan berbeda, 6) mendengarkan intuisi. Dengan kata lain, kemampuan berfikir kreatif siswa adalah kemampuan siswa dalam memahami masalah dan menemukan penyelesaian dengan strategi atau metode yang bervariasi (divergen)

\section{Berfikir Kreatif dalam Matematika}

Berfikir kreatif dalam pembelajaran matematika, dapat dipandang sebagai orientasi atau disposisi tentang instruksi matematika, termasuk tugas penemuan dan pemecahan masalah. Aktifitas ini dapat membawa siswa mengembangkan pendekatan yang lebih kreatif dalam matematika. Dengan tugas dan aktifitas ini, guru dapat meningkatkan kapasitas siswa dalam hal yang berkenaan dengan dimensi kreatifitas. Menurut Suryadi dan Herman; berpikir kreatif merupakan suatu proses berpikir untuk mengungkapkan hubungan-hubungan baru, melihat sesuatu dari sudut pandang baru dan membentuk kombinasi baru dari dua konsep atau lebih yang sudah dikuasai sebelumnya.

Selanjutnya, Munandar, Utami (1992) mendefinisikan berpikir kreatif sebagai kemampuan yang mencerminkan kelancaran, keluwesan (fleksibilitas), dan orisinalitas (keaslian) dalam berpikir, secara kemampuan untuk mengelaborasi (mengembangkan, memperkaya, memperinci) suatu gagasan.

Berdasarkan analisis faktor, Guilford dalam Suryadi menemukan bahwa ada lima sifat yang menjadi ciri berpikir kreatif, yaitu: 1 . Kelancaran (fluency), merupakan kemampuan untuk menghasilkan banyak gagasan 2. Keluwesan (flexibility), merupakan kemampuan untuk mengemukakan beberapa pemecahan atau pendekatan terhadap masalah, 3. Keaslian (originality), orisinalitas adalah kemampuan untuk mencetuskan gagasan dengan cara-cara yang asli, tidak klise 4. Penguraian (elaboration), elaborasi adalah kemampuan untuk menguraikan sesuatu secara terinci 5 . Perumusan kembali (redefinition), redefinisi adalah kemampuan untuk meninjau suatu persoalan berdasarkan perspektif yang berbeda dengan apa yang sudah diketahui oleh banyak orang (Suryadi, Didi \& Tatang Herman: 2008)

Pada saat ini, perhatian banyak tertuju pada kemampuan berpikir kreatif (kreativitas) sebagai suatu produk dari hasil pemikiran atau perilaku manusia. Untuk mengenali kemampuan berfikir kreatif dalam matematika menggunakan dua pendekatan seperti berikut; 1) memperhatikan jawaban siswa dalam memecahkan masalah yang proses kognitifnya dianggap sebagai proses berfikir kreatif, 2) menentukan kriteria bagi sebuah produk yang diindikasikan sebagai hasil dari berfikir kreatif atau sebagai produk-produk divergen.

Kemampuan berpikir kreatif dapat pula dilihat sebagai suatu proses dan mungkin inilah yang lebih esensial dan yang perlu dibina pada anak didik sejak dini untuk bersibuk diri secara kreatif. Sriraman mendefinisikan kreatifitas sebagai proses yang hasilnya tidak biasa, solusi yang dalam dari persoalan yang diberikan dan terlepas dari tingkat kompleksitas

Indikatornya meliputi; 1) kefasihan/ kelancaran (fluency), yaitu kemampuan untuk mengemukakan ide, jawaban, pertanyaan, dan penyelesaian masalah, 2) keluwesan (flexibility), yaitu kemampuan untuk menemukan atau menghasilkan berbagai macam ide, jawaban, atau pertanyaan yang bervariasi, 3) penguraian (elaboration), yaitu kemampuan untuk mengembangkan suatu ide, menambah atau merinci secara detil suatu obyek, ide, dan situasi, 4) hal yang baru (originality), yaitu kemampuan untuk memberikan respon-respon yang untik dan luar biasa. Dalam penelitian ini akan diidentifikasi kemampuan berpikir kreatif siswa dalam hal: (a) kelancaran (fluency), yaitu menghasilkan banyak ide atau gagasan dalam 
bentuk pertanyaan atau pernyataan yang bernilai benar dari informasi yang diberikan dengan tepat, (b) keluwesan (flexibility), yaitu mengemukakan ide yang beragam pada pertanyaan atau pernyataan yang disusun, dan (c) keaslian (originality), yaitu memunculkan ideide yang unik dalam menyusun pertanyaan atau pernyataan dengan tepat.

\section{METODE PENELITIAN}

Jenis peneltian yang digunakan dalam penelitian ini quasi eksperimen (eksperimen semu). Desain penelitian yang digunakan adalah Desain Kelompok Kontrol Non-Ekuivalen.

Adapun populasi dalam penelitian ini adalah seluruh siswa kelas $X$ yang berjumlah 4 kelas yang terdiri dari kelas IPS-1, IPS-2, IPA-1 dan IPA-2 yang berjumlah 238 orang.

Sedangkan yang menjadi sampel adalah perwakilan dari populasi yang diambil secara purposive sampling yaitu pengambilan sampel berdasarkan tujuan penelitian. Adapun yang menjadi sampel adalah siswa kelas X MIA/IPA 1 (kelas eksperimen) dan MIA/IPA 2 (kelas kontrol) di SMA KAE Woha Bima Tahun Pelajaran 2017/2018. Pemilihan kelas untuk jadi kelas penelitian yaitu pemilihan secara acak ( random).

Instrumen penelitian ini sangat diperlukan untuk menjawab masalah-masalah penelitian dan untuk menguji hipotesis. Dari instrumen penelitian ini, penulis dapat mengukur data kuantitatif yang terdapat dalam variabel. Supaya tidak terdapat keraguan dan dapat memperterang arti dari variabel yang ada, sehingga dapat digunakan secara operasional. Adapun instrumen yang digunakan untuk mengukur kemampuan berpikir kreatif adalah melalui

\section{Teknik Analisis Data}

\section{Uji Normalitas}

Ujinormalitas bertujuan untuk mengetahui apakah data berdistrubusi normal ataukah tidak. Pada uji normalitas ini digunakan metode Kolmogorov-Smirnov. Keputusan uji dan kesimpulan diambil pada taraf signifikansi 0,05 dengan keriteria: 1) jika nilai signifikan lebih besar dari 0,05 maka $\mathrm{H}_{\mathrm{a}}$ diterima, sehingga data berdistribusi normal, 2) jika nilai signifikansi lebih kecil dari 0,05 maka $\mathrm{H}_{0}$ ditolak, sehingga data tidak berdistribusi normal. Uji normalitas ini dilakukan dengan menggunakan bantuan program software SPSS 16 for windows.

\section{Uji Homogenitas}

Uji homogenitas mempunyai tujuan untuk mengetahui apakah pada kelompok eksperimen dan kelompok kontrol mempuanyai varian yang homogeny atau tidak. Uji homogenitas ini dilakukan dengan menggunakan bantuan program software SPSS 16 for windows.

Uji homogenitas dan penarikan kesimpulan terhadap uji hipotesis dilakukan pada taraf signifikansi $5 \%(0,05)$. Pedoman pengambilan keputusan uji homogenitas sebagai berikut: 1) nilai signifikansi atau nilai probabilitas kurang dari 0,05 maka data berasal dari populasipopulasi yang mempunyai varians yang tidak homogen, dan 2) nilai signifikansi atau nilai probabilitas lebih dari 0,05 maka data berasal dari populasi-populasi yang mempunyai varians yang homogen.

\section{Pengujian Hipotesis}

Setelah melakukan uji normalitas dan uji homogenitas terhadap kemampuan berpikir kreatif siswa selanjutnya adalah melakukan analisis uji-t untuk mengetahui pengaruh penggunaan model pembelajaran Reciprocal Teaching. Dalam hal ini uji statistik yang digunakan adalah uji statistik uji $\mathrm{t}$

Adapun rumus uji-t yang digunakan yaitu sebagai berikut:

$$
\mathrm{t}=\frac{x-\bar{x}}{\sqrt[5]{\frac{1}{n_{1}}+\frac{1}{n_{2}}}}
$$

Dimana:

$\mathrm{Xi}=$ Rata-rata kelompok pembelajaran tanpa perlakuan

$\bar{x}=$ Rata-rata kelompok pembelajaran dengan perlakuan

$\mathrm{S}=$ Variansi gabungan

$\mathrm{n}_{1}=$ jumlah sampel kelompok pembelajaran tanpa perlakuan

$\mathrm{n}_{2}=$ Jumlah sampel kelompok pembelajaran dengan perlakuan

Dari $t_{\text {hitung }}$ yang diperoleh kemudian dikonsultasikan dengan $t_{\text {tabel }}$ yang memiliki derajat kebebasan $\mathrm{dk}=\mathrm{N}_{1}+\mathrm{N}_{2}-2$ dan taraf 
signifikansi $\alpha=5 \%$. Kriteria pengujian adalah tolak.

\section{HASIL PENELITIAN}

Tabel 1. Deskripsi Data Hasil Tes Kemampuan Berpikir Kreatif Siswa.

\begin{tabular}{ccccc}
\hline \multirow{2}{*}{ Deskripsi } & \multicolumn{2}{c}{$\begin{array}{c}\text { Kelompok } \\
\text { Eksperimen }\end{array}$} & \multicolumn{2}{c}{$\begin{array}{c}\text { Kelompok } \\
\text { Kontrol }\end{array}$} \\
\cline { 2 - 5 } & Pretes & Post-tes & Pretes & Post-tes \\
\hline Rata-rata & 58.14 & 66.42 & 54.85 & 54.85 \\
\hline Nilai max & 75.00 & 85.00 & 60.00 & 70.00 \\
\hline Nilai min & 45.00 & 50.00 & 30.00 & 40.00 \\
\hline
\end{tabular}

Perbandingan Kemampuan Berpikir Kreatif Antara Kelas Eksperimen (reciprocal teaching) Dengan Kelas Kontrol.

Untuk data yang diperolehdaripretest dan posttest, baik kemampuan berpikir kreatif antara kelas eksperimen (reciprocal teaching) dengan kelas control sebelum dan setelah treatment, asumsi normalitas dan homogenitas harus dipenuhi. Karenaasumsi-asumsi yang menjadi prasyarat untuk menerapkan analisis uji multivariat. Data yang dianalisis adalah data yang diperoleh dari pretest dan posttest dan hasil pengukuran kemampuan berpikir kreatif antara kelas eksperimen dengan kelas kontrol.

\section{Data Sebelum Perlakuan}

Data yang diperoleh sebelum treatment meliputi data hasil pengukuran kemampuan berpikir kreatif baik untuk kelas eksperimen maupun kelas kontrol.

\section{Uji Normalitas}

Uji normalitas dilakukan pada kedua kelompok yaitu kelas yang menggunakan metode pembelajaran reciprocal teaching dan kelas kontroluntuk mengetahui apakah populasi berdistribusi normal atau tidak. Hasil pengukuran metode pembelajaran reciprocal teaching dan kelas kontrol pada kedua kelas berdistribusi normal. Hasil menggunakan softwareSPSS 16 for window dapat lihat pada tabel sebagai berikut:

Tabel 2. Uji Normalitas Kondisi Awal

\begin{tabular}{cccc}
\hline Kelas & Tes & Nilai Sig & Kriteria \\
\hline \multirow{2}{*}{ Eksperimen } & Pretest & 0,404 & Normal \\
\cline { 2 - 4 } & Postets & 0,557 & Normal \\
\hline \multirow{2}{*}{ Kontrol } & Pretest & 0,476 & Normal \\
\cline { 2 - 4 } & Postets & 0,476 & Normal \\
\hline
\end{tabular}

\section{Uji Homogenitas}

Uji homogenitas dimaksudkan untuk menguji kemampuan awal kedua kelas terhadap kemampuan berpikir kreatif. Nilai Levene statistic 0,617 dan sig. 0,715 Ini menunjukkan bahwa kemampuan berpikir kreatif siswa kedua kelas homogen.

\section{Uji Hipotesis}

Kriteria pengujiannya adalah $\mathrm{H}_{0}$ ditolak jika $t_{\text {hitung }} \geq t_{\text {tabel }}$ atau nilai signifikansi lebih kecil 0,05 pada taraf sinikansi $\alpha=5 \%$. Hasil Uji hipotesis menggunakan bantuan program SPSS 16 for window menunjukkan nilai $\mathrm{t}=4,128$ atau nilai signifikansi adalah 0,000. Jika dikaitkan dengan nilai signifikansi 0,05 maka $\mathrm{H}_{\mathrm{a}}$ diterima. Sehingga dapat disimpulkan bahwa terdapat pengaruh penggunaan metode reciprocal teaching terhadap kemampuan berpikir kreatif siswa. Hasil analisis selengkapnya dapat dilihat pada lampiran.

\section{Pembahasan}

Menerapkan metode pembelajaran reciprocal teaching bertujuan untuk memperbaiki proses pembelajaran yang terjadi dalam kelas dan diharapkan berimplikasi baik pada hasil yang akan dicapai. Tidak efektifnya pembelajaran yang terjadi maka bisa dikatakan bahwa pembelajaran yang diterapkan tersebut tidak efektif pada tujuan pembelajaran yang telah ditetapkan. Sebelum melihat efek dan membandingkan kedua variabel, yang perlu diperhatikan lebih awal adalah kemampuan berpikir kreatif siswa.

Pada metode pembelajaran reciprocal teaching dan kemampuan berpikir kreatif siswa kelas X SMAS KAE Woha Bima dapat dilihat dari kriteria ketuntasan minimal (KKM) yang telah ditentukan untuk masing-masing variabel dependen. KKM yang telah ditentukan untuk menggunakan metode reciprocal teaching untuk mengatasi permasalahan disekolah tersebut, sehingga melalui proses tersebut dapat mengingkatkan kemampuan berpikir kreatif siswa,sedangkan untuk mengukur hasil kemampuan berpikir kreatif siswa antara kelas eksperimen dengan kelas kontrol dapat dikatakan berhasil apabila mendapat jumlah skor minimal 100. 
Pembelajaran reciprocal teaching ditinjau dari kemampuan berpikir kraetif siswa sejalan dengan kajian teori dan hasil penelitian, Menurut Suyatno (2009: 64) Reciprocal teaching merupakan strategi pembelajaran berdasarkan prinsip-prinsip pengajuan pertanyaan dimana ketrampilan-ketrampilan metakognitif siswa diajarkan melalui pengajaran langsung dan pemodelan oleh guru. (Antari, Sujana, Wiarta: 2013) model reciprocal teaching (pembelajaran terbalik) merupakan salah satu model pembelajaran kooperatif yang menekankan pada partisipasi dan aktivitas siswa dalam proses pembelajaran. Dengan pembelajaran terbalik ini siswa diajarkan empat strategis yaitu: (1) membuat rangkuman, (2) menyusun pertanyaan, (3) memprediksi jawaban, (4) dan menjelaskan kembali isi materi (bacaan) tersebut kepada siswa lain. Reciprocal teaching (pembelajaran terbalik) dalam pembelajaran matematika dapat membelajarkan siswa untuk belajar mandiri dengan menerapkan emapt strategis pemahaman tersebut melalui bacaan yang diberikan oleh guru.

Menurut Misi Mayona (2012) mencatat materi pelajaran bertujuan meningkatkan daya ingat, sehingga konsep dapat dipahami dengan baik.

\section{KESIMPULAN}

Dari hasil analisis data dapat disimpulkan bahwa terdapat pengaruh penggunaan metode reciprocal teaching terhadap kemampuan berpikir kreatif siswa. Nilai $\mathrm{t}=4,128$ atau nilai signifikansi adalah 0,000. Jika dikaitkan dengan nilai signifikansi yang lebih kecil dari 0,05 maka $\mathrm{H}_{\mathrm{a}}$ diterima

\section{DAFTAR PUSTAKA}

Fatmah, F., \& Rahman, A. (2017). pembelajaran Langsung Berbantuan Media Gambar Fotografi untuk Membantu Mahasiswa Membangun Konsep Himpunan. Jurnal Ilmiah Mandala Education (JIME), 3 (2), 249. 258.

Nasution. 2008. Berbagai Pendekatan Dalam Proses Belajar Mengajar. Bandung: Bumi Aksara .
Semiawan, Cony. 1987. Memupuk Bakat dan Kreativitas Siswa Sekolah Menengah. Jakarta: Gramedia

Slameto. 2003. Belajar dan Faktor-Faktor yang Mempengaruhinya. Jakarta: PT. Rineka Cipta.

Sudjana, Nana. 2010. Penilaian Hasil Proses Belajar Mengajar. (Cet. XV). Bandung: PT. Ramaja Rosdakarya. Suyatno. 2009. Menjelajah Pembelajaran Inovatif. Sidoarjo: Masmedia Buana Pustaka.

Siswono. 2007. Penjenjangan Kemampuan Berpikir Kreatif dan Identifikasi Tahap Berpikir Kreatif Siswa dalam Memecahkan dan Mengajukan Masalah Matematika, hal. 1,[online]:

http://tatagyes.wordpress.com/abstrakdisertasi/. diakses 23 Juli 2013

Suryadi, Didi \& Tatang Herman. 2008. Eksplorasi Matematika Pembelajaran Pemecahan Masalah. Jakarta: Karya Duta Wahana

Trianto. 2007. Model Pembelajaran Inovatif berorentasi kontruktivistis. Jakarta: Prestasi Pustaka. 